\title{
VOLUME AND HEAT TRANSPORTS ANALYSIS IN THE SOUTH ATLANTIC BASIN RELATED TO CLIMATE CHANGE SCENARIOS
}

\author{
Lívia Maria Barbosa Sancho ${ }^{1}$, Luiz Paulo de Freitas Assad² and Luiz Landau ${ }^{1}$
}

\begin{abstract}
This study evaluates how climate change might affect advective heat and volume transports in the South Atlantic Basin based on Intergovernmental Panel on Climate Change (IPCC) A1FI and B1 climate change scenarios projections. Using the Climatic Model 2.1 (CM2.1) results that were developed by the Geophysical Fluid Dynamics Laboratory (GFDL), integrated on the water column, analyses were conducted through two meridional sections and one zonal section of the study area (between $25^{\circ} \mathrm{S}-70^{\circ} \mathrm{S}$ and $70^{\circ} \mathrm{W}-20^{\circ} \mathrm{E}$ ). The annual mean time series were analyzed using historical 100 -year climate change scenarios. The analyses of the climate change experiment parameters were compared with those of the $\mathrm{H} 2$ climate scenario. The volume transport (VT) through the water column weakened of about $5 \%$ in average and the advective heat transport (HT) increased of about $22 \%$ at the Drake and Africa-Antarctic (AF-AA) passages at the end of the experiments. For the zonal section at $25^{\circ} \mathrm{S}$, direction oscillations were observed in the integrated VT through the water column due to velocity intensity variations of the water masses and a decrease of about $22 \%$ in the HT was observed. Thus, it was observed a decrease in the water and heat supplies at $25^{\circ} \mathrm{S}$ due to the Drake and AF-AA VT behavior, which may alter deep circulation patterns.
\end{abstract}

Keywords: water column analysis, advective heat transport, flow direction, Drake Passage, Africa-Antarctic passage.

RESUMO. Baseado nas projeções dos cenários de mudanças climáticas A1Fl e B1 do Painel Intergovernamental de Mudanças Climáticas (IPCC), esse estudo avalia como as mudanças climáticas podem impactar os transportes advectivos de calor e volume na bacia do Atlântico Sul. Através de resultados gerados pelo Modelo Climático 2.1 (CM2.1) desenvolvido pelo Geophysical Fluid Dynamics Laboratory (GFDL), foram feitas análises através de duas seções meridionais e uma seção zonal na área de estudo (entre $25^{\circ} \mathrm{S}-70^{\circ} \mathrm{S}$ e $70^{\circ} \mathrm{W}-20^{\circ} \mathrm{E}$ ) integradas na coluna d'água. Foram analisados campos prognósticos médios anuais referentes a experimentos com 100 anos de duração. As análises dos parâmetros dos experimentos de mudanças climáticas foram realizadas em comparação com 0 experimento clima (H2). 0 transporte de volume (TV) integrado na coluna d'água enfraqueceu aproximadamente 5\%, enquanto 0 transporte advectivo de calor (TC) aumentou em torno de 22\% no Drake e na Passagem África-Antártida (AF-AA) ao final dos experimentos. Para a seção em $25^{\circ} \mathrm{S}$, foram observadas oscilações de direção do fluxo devido a variações na intensidade das velocidades das massas d’água com um enfraquecimento médio de $22 \%$ para 0 TC. Adicionalmente, foi observada uma diminuição no suprimento de água em $25^{\circ} \mathrm{S}$ devido ao comportamento do TV das demais seções, o que pode alterar os padrões de circulação profunda.

Palavras-chave: análise na coluna d'água, transporte advectivo de calor, direção do fluxo, Passagem de Drake, passagem África-Antártida.

\footnotetext{
1 Instituto Alberto Luiz Coimbra de Pós-Graduação e Pesquisa de Engenharia, Universidade Federal do Rio de Janeiro - COPPE/UFRJ, Programa de Engenharia Civil, Laboratório de Métodos Computacionais em Engenharia, Av. Athos da Silveira Ramos, 149, Cidade Universitária, Ilha do Fundão, 21941-909 Rio de Janeiro, RJ, Brazil. Phones: +55(21) 2562-8419/2562-8415 - E-mails: sancho@lamce.coppe.ufrj.br; landau@lamce.coppe.ufrj.br

2 Universidade Federal do Rio de Janeiro - UFRJ, Departamento de Meteorologia, Av. Athos da Silveira Ramos, 274, Cidade Universitária, Ilha do Fundão, 21941-916 Rio de Janeiro, RJ, Brazil - E-mail: Ipaulo@lamce.coppe.ufrj.br
} 


\section{INTRODUCTION}

The interactions between atmosphere-ocean circulation and global climate patterns are widely recognized (Houghton, 2004, 2009; Bollmann et al., 2010). It is therefore of fundamental importance to understand how global climate changes might affect ocean circulation and the potential implications to future climate patterns. The South Atlantic Ocean (SA) plays an important role in the global oceanic circulation by transferring heat to the North Atlantic Ocean (NA) (Evans \& Signorini, 1985; Peterson \& Stramma, 1991; Rintoul, 1991; Broecker, 1997; Campos et al., 1999; Ganachaud \& Wunsch, 2000; Stammer et al., 2003; Stouffer et al., 2006; Stewart, 2008; Assad et al., 2009; Bollmann et al., 2010; Yaohua et al., 2014). Consequently, this heat transfer alleviates the climate of several regions, such as northeastern Europe (Broecker, 1997; Stewart, 2008). Therefore, changes on the greenhouse gases concentration may have a deep impact on the ocean circulation and, consequently, on the global climate.

This heat transfer is part of a large global circulation, first introduced by Broecker (1991) with the two-layer thermohaline flow scheme. In the study, the Thermohaline Circulation is forced by the North Atlantic Deep Water (NADW). This water mass, formed in high latitudes of the NA, influence and is largely influenced by the Antarctic Bottom Water (AABW) and the Antarctic Intermediate Water (AAIW) (Tomczak \& Godfrey, 1994; Clarke et al., 2001; Talley et al., 2011). According to Pond \& Pickard (1983), the main contributions for the NADW formation are Iocated on the NA and the SA.

Once formed by deep convection (Grassl, 2001), the NADW sinks and flows southward as the Deep Boundary Current (DBC) where part of it merges with the Antarctic Circumpolar Current (AACC) and is exported to the Indian Ocean (Clarke et al., 2001). Donners et al. (2005) estimated in $15.0 \mathrm{~Sv}$ the volume of NADW exported from the SA, which agrees with the $15.0 \pm 12.0 \mathrm{~Sv}$ of deep water formation in the North Atlantic from Ganachaud \& Wunsch (2000). According to Broecker (1991), to compensate this deep cold flow, a surface warm flow enters the SA through the Indian Ocean.

The SA receives fluxes from the Pacific Ocean through the Drake Passage, from the Indian Ocean, through the Agulhas Current Retroflexion (ACR) and from the NA (Peterson \& Stramma, 1991; Campos et al., 1999; Gordon, 2003; Garlozi; Baringer, 2007; Biastoch et al., 2009). Rintoul (1991), through historic hydrographic data and inverse methods, calculated intense fluxes (velocities over $70 \mathrm{~cm} \mathrm{~s}^{-1}$ ) associated with the ACR for a $30^{\circ} \mathrm{E}$ section in the SA. For the Drake Passage and a section on the $0^{\circ}$ meridian, the author found eastward volume transports of
130.0 Sv for both sections and a northward heat transport of $0.25 \mathrm{PW}$ across the $32^{\circ} \mathrm{S}$ parallel.

Ganachaud \& Wunsch (2000), through an inverse hydrographic method, estimated the geostrophic velocity fields related to volume transport for the Drake and the $32^{\circ} \mathrm{S}$ parallel in the $\mathrm{SA}$, and identified a eastward flow of $140.0 \pm 13.0 \mathrm{~Sv}$ and a northern flow of $16.0 \pm 3.0 \mathrm{~Sv}$ of thermocline water, respectively. The authors also estimated the heat transport across the Drake Passage of $1.30 \mathrm{PW}$ also moving eastward.

Cunningham et al. (2003), through six WOCE hydrographic sections between 1993 and 2000, estimated the transport across Drake Passage. The authors calculated the average net baroclinic transport of this region relative to the bottom as $136.7 \pm 7.8 \mathrm{~Sv}$. From the same year, Stammer et al. (2003), through a fully constrained general circulation model forced by a time-varying global ocean data sets over 1993 to 2000 using the data synthesis, or state estimation method, estimated the volume and heat transports through several sections on the World Ocean. For the volume transport, the authors calculated values of $124.0 \pm 5.0 \mathrm{~Sv}$ and $124.0 \pm 6.0 \mathrm{~Sv}$ moving eastward for Drake and AF-AA, respectively. For the heat transports, the authors estimated $1.14 \pm 0.0600$ PW and $1.01 \pm 0.1500$ PW also moving eastward for the two sections, respectively and $0.27 \pm 0.2500 \mathrm{PW}$ moving northward for both the $32^{\circ} \mathrm{S}$ and $20^{\circ} \mathrm{S}$ parallels.

Garlozi \& Baringer (2007), in a transatlantic cruise along $35^{\circ} \mathrm{S}$, observed a total northward heat transport of $0.60 \pm$ 0.1800 PW across the parallel for March 2004. At $34^{\circ} 20^{\prime}$ 's, the authors identified a value of $0.49 \pm 0.1800$ PW for May 2006 . Using a Global Ocean Circulation Model, Assad et al. (2009) calculated the volume and heat transports through several zonal and meridional sections. The authors estimated the volume transport integrated in the water column at the Drake and AfricaAntarctic passages; for these sections, the authors obtained eastward-flowing values of $141.3 \pm 11.1 \mathrm{~Sv}$ and $143.9 \pm 10.8 \mathrm{~Sv}$, respectively. For the advected heat transport, the authors calculated column-integrated eastward values of $1.52 \pm 0.0008$ PW and $0.98 \pm 0.0040$ PW for the Drake and AF-AA passages. For the $32^{\circ} \mathrm{S}$ parallel, the authors found $0.60 \pm 0.0200 \mathrm{PW}$ towards the equator.

Zheng \& Giese (2009), through a 1958-2004 period of Simple Ocean Data Assimilation (SODA) analysis, estimated the heat transport through several sections on the World Ocean. The long-term mean and standard deviation without the annual cycle of the eastward heat transport for the Drake and AF-AA passages were $1.65 \pm 0.0700 \mathrm{PW}$ and $0.94 \pm 0.1200 \mathrm{PW}$, respectively and for the $30^{\circ} \mathrm{S}$ and $20^{\circ} \mathrm{S}$ parallels, the heat 
transport values were $0.59 \pm 0.0700 \mathrm{PW}$ and $0.69 \pm 0.0800 \mathrm{PW}$, respectively.

The authors found synchronous changes of the meridional heat transport at low to mid-latitudes and the strength of the Atlantic Meridional Overturning Circulation (MOC) rather than with South Atlantic Subtropical Gyre. They also found that decreases in surface density on water formation sites on the northern NA with the likely consequence of slowing down the sinking process, may be an important factor of the MOC strength variability. The analysis suggest that a freshening in the Labrador Sea together with a decrease overflow weakens the MOC.

Yaohua et al. (2014), through a 1400-year spin up results from the MOM4p1 started from the rest and driven by monthly climatological mean force from the NOAA World Ocean Atlas (1994), estimated the annual mean volume and heat transport through the inter-basin passages and transoceanic sections. The authors estimated the transports through Drake and AF-AA passages and for the $30^{\circ} \mathrm{S}$ and $0^{\circ}$ parallels. The volume transport estimations were $177.0 \mathrm{~Sv}$ and $177.7 \mathrm{~Sv}$ moving eastward at Drake and AF-AA, respectively and $0.46 \mathrm{~Sv}$ and $0.98 \mathrm{~Sv}$ moving southward at $32^{\circ} \mathrm{S}$ and $0^{\circ}$. For the heat transport, the authors obtained 1.77 PW and 1.70 PW moving eastward at Drake and
AF-AA, respectively and 0.01 PW and 0.26 PW moving northward at $32^{\circ} \mathrm{S}$ and $0^{\circ}$. A summary of the mentioned works is displayed on Table 1.

This work aims to analyze the interannual variations of the SA heat and volume transports associated with the A1FI and B1 climate change scenarios results that were generated by the Geophysical Fluid Dynamics Laboratory's (GFDL) Coupled Climatic Model 2.1 (CM2.1).

\section{THE DATASET}

The dataset used aim to simulate climate conditions (past, present or future) using the GFDL's CM2.1. Since 1955, the GFDL has significantly contributed to the worldwide research on climate change. In fact, the GFDL has been a collaborator on all of the IPCC's climate change reports. Hence, the model results and climate change scenarios disclosed in the climate change reports have contributed to the global knowledge on climate change.

The CM2.1 is a global coupled climate model used to conduct simulations for the $4^{\text {th }}$ IPCC report in 2007. The model represents the main climate system components and their interactions. The advantage of using climate model results is that they effectively

Table 1 - Summary of the total Volume (VT) and Heat Transports (HT) values conducted in the study area. The letters next to each value indicate the flow direction: $\mathrm{N}$ - northward, $\mathrm{S}$ - southward and $\mathrm{E}$ - eastward.

\begin{tabular}{|c|c|c|c|}
\hline Author & Section & VT (Sv) & HT (PW) \\
\hline \multirow{3}{*}{ Rintoul (1991) } & Drake & $130.00 \pm 13.00 E$ & - \\
\hline & $0^{\circ}$ Iongitude & 130.00E & - \\
\hline & $32^{\circ} \mathrm{S}$ & - & $0.25 \mathrm{~N}$ \\
\hline Ganachaud \& Wunsch (2000) & Drake & $140.00 \pm 6.00 \mathrm{E}$ & $1.30 \mathrm{E}$ \\
\hline Cunningham et al. (2003) & Drake & $136.70 \pm 7.80 \mathrm{E}$ & - \\
\hline \multirow{4}{*}{ Stammer et al. (2003) } & Drake & $124.00 \pm 5.00 \mathrm{E}$ & $1.14 \pm 0.0600 \mathrm{E}$ \\
\hline & AF-AA & $124.00 \pm 6.00 \mathrm{E}$ & $1.01 \pm 0.1500 \mathrm{E}$ \\
\hline & $32^{\circ} \mathrm{S}$ & $0 \pm 1.90$ & $0.27 \pm 0.2500 \mathrm{~N}$ \\
\hline & $20^{\circ} \mathrm{S}$ & $0 \pm 1.60$ & $0.27 \pm 0.2500 \mathrm{~N}$ \\
\hline \multirow{2}{*}{ Garlozi \& Baringer (2007) } & $35^{\circ} \mathrm{S}$ & - & $0.60 \pm 0.1800 \mathrm{~N}$ \\
\hline & $34^{\circ} 20^{\prime} \mathrm{S}$ & - & $0.49 \pm 0.1800 \mathrm{~N}$ \\
\hline \multirow{3}{*}{ Assad et al. (2009) } & Drake & $141.30 \pm 11.10 \mathrm{E}$ & $1.52 \pm 0.0008 \mathrm{E}$ \\
\hline & AF-AA & $143.90 \pm 10.80 \mathrm{E}$ & $0.98 \pm 0.0040 \mathrm{E}$ \\
\hline & $32^{\circ} \mathrm{S}$ & - & $0.60 \pm 0.0200 \mathrm{~N}$ \\
\hline \multirow{4}{*}{ Zheng \& Giese (2009) } & Drake & - & $1.65 \pm 0.0700 \mathrm{E}$ \\
\hline & AF-AA & - & $0.94 \pm 0.1200 \mathrm{E}$ \\
\hline & $30^{\circ} \mathrm{S}$ & - & $0.59 \pm 0.0700 \mathrm{~N}$ \\
\hline & $20^{\circ} \mathrm{S}$ & - & $0.69 \pm 0.0800 \mathrm{~N}$ \\
\hline \multirow{4}{*}{ Yaohua et al. (2014) } & Drake & $177.00 \mathrm{E}$ & $1.77 \mathrm{E}$ \\
\hline & AF-AA & $177.70 \mathrm{E}$ & $1.60 \mathrm{E}$ \\
\hline & $30^{\circ} \mathrm{S}$ & $0.46 \mathrm{~S}$ & $0.01 \mathrm{~N}$ \\
\hline & $0^{\circ}$ latitude & $0.98 \mathrm{~S}$ & $0.26 \mathrm{~N}$ \\
\hline
\end{tabular}


represent the exchange of mass and energy between the different components of the climate system. For the proposed work, this fact is of fundamental importance because it ensures that greenhouse gas-forced changes in the atmosphere and other climate system components are transfered to the ocean. The climate model considers the atmosphere, lithosphere, hydrosphere and cryosphere. It simulates the most important processes of each component and their interactions (e.g., heat, mass, and energy exchanges) (Delworth et al., 2006; Mkhandi et al., 2008).

\section{THE CLIMATE MODEL EXPERIMENTS}

The methodology consists of using the CM2.1 results provided by the GFDL, which is administered by the National Oceanic and Atmospheric Administration (NOAA). The experiments use the CM2.1 oceanic component, referenced in the literature as the OM 3.1 (Griffies et al., 2005; Delworth et al., 2006; Gnanadesikan et al., 2006; Mkhandi et al., 2008), which is based on the Modular Ocean Model (MOM4). This model was initially developed to study the ocean climate system. It is idealized and supported by the GFDL but receives worldwide contributions, since it has an opened code (Griffies et al., 2008).

The simulations used a horizontal finite difference meridional grid of $1^{\circ}$ and zonal grid of $1 / 3^{\circ}$ between $10^{\circ} \mathrm{N}$ and $10^{\circ} \mathrm{S}$, relaxing to $1^{\circ}$ towards the poles. The vertical grid is discretized in $z$-coordinates with 50 levels; the first 22 with 10-m thickness each (Delworth et al., 2006; Gnanadesikan et al., 2006). A tripolar grid is also used (Murray, 1996). A detailed description of the model components and underpinning science is provided in Griffies et al. (2000; 2005; 2008), Delworth et al. (2006), Gnanadesikan et al. (2006), Stouffer et al. (2006), Wittenberg (2006), Mkhandi et al. (2008) and Assad (2011).

The climate change scenarios germane to this research aimed to simulate future conditions of the global climate, beginning with the current climate. The results from two CM2.1 climate change scenarios (A1FI and B1), along with a past condition scenario $(\mathrm{H} 2)$ were obtained. The prognostic fields were acquired in monthly averages and were used to estimate annual averages. The $\mathrm{H} 2$ experiment (climate), characterizes the twentieth century climate. The second experiment, A1FI, simulates a fossil fuelintensive scenario. The third experiment, $\mathrm{B} 1$, is characterized by a stabilizing $\mathrm{CO}_{2}$ concentration at the end of the study period (see Houghton (2009), Fig. 6.1). The A1FI scenario is the most critical between the IPCC's $4^{\text {th }}$ Assessement Report (AR4) while B1 scenario tends to achieve stabilization. A basic description for the scenarios is depicted on Table 2. More information about the scenarios can be found directly at gfdl.noaa.gov, AR4 (2007) and Houghton (2009).
The oceanic variables extracted from the numerical experiments were the zonal and meridional velocity, potential temperature and salinity. The volume (VT) and heat (HT) transports were estimated as annual means using Eq. (1) and Eq. (2), respectively. The VT is a result of integrating the velocity component normal to the section, and the HT is the result of integrating the velocity component normal to the section multiplied by the density and temperature of the sea water and the specific heat. Thus, the VT (HT) represents the resulting zonal or meridional volume (heat) transport through the water column. The average anomaly fields for the VT and HT were estimated for 2050 and 2100 for each climate change scenario relative to the year 2000 of the climate experiment (Eq. 3).

$$
\begin{gathered}
V_{t}=\int_{0}^{L} \int_{-h(z)}^{0} \nu(x, z, t) d z d x \\
H_{t}=\rho \cdot c_{p} \int_{0}^{L} \int_{-h(z)}^{0} \nu(x, z, t) \cdot \theta d z d x \\
\text { Anomaly }=\varnothing_{A 1 F I \text { or } B 1}-\varnothing_{\text {climate }}
\end{gathered}
$$

$$
\begin{array}{ll}
\text { where } & \\
V_{t} & - \text { Volume transport } \\
H_{t} & - \text { Heat transport } \\
\nu & - \text { Velocity component normal to the section } \\
L & - \text { Lateral dimension limit } \\
-h_{(z)} & - \text { Vertical dimension limit } \\
z & - \text { Vertical dimension } \\
x & - \text { Lateral dimension } \\
\rho & - \text { Sea water density } \\
\theta & - \text { Potential temperature } \\
c_{p} & - \text { Sea water specific heat } \\
\varnothing & - \text { Considered property for the anomaly calculation. }
\end{array}
$$

\section{DESCRIPTION OF THE MONITORED OCEANIC SECTIONS}

One zonal and two meridional sections in the SA were defined between $25^{\circ} \mathrm{S}-70^{\circ} \mathrm{S}$ and $70^{\circ} \mathrm{W}-20^{\circ} \mathrm{E}$. In these locations, the volume and heat transports were estimated for the identified experiments. These monitored sections represent the Drake Passage, the passage between Africa-Antarctica (AF-AA) and the $25^{\circ} \mathrm{S}$ parallel (Fig. 1).

The sections were chosen to represent the volume and heat transports balance in the bounded regions. Thus, the sections of the Drake and AF-AA were selected because they represent the connection regions between the AS and adjacent basins. The $25^{\circ} \mathrm{S}$ section was selected because of the importance of this ocean as an exporter of heat to the NA. Additionally, these 
Table 2 - Basic description of the scenarios used based on GFDL (2006a; 2006b; 2006c).

\begin{tabular}{|c|c|c|c|c|c|}
\hline \multirow{2}{*}{ Scenarios } & \multicolumn{3}{|c|}{ Time (years) } & \multirow{2}{*}{$\begin{array}{c}\text { Initial } \\
\text { conditions }\end{array}$} & \multirow{2}{*}{ Boundary conditions } \\
\hline & Simulated & & d in study & & \\
\hline $\mathrm{H} 2$ & 140 & & $\begin{array}{c}\text { from } \\
1901-2000\end{array}$ & control-1860 ${ }^{1}$ & $\begin{array}{l}\text { Observations and reconstructions } \\
\text { from XIX and XX centuries }\end{array}$ \\
\hline $\mathrm{A} 1 \mathrm{FI}$ & 100 & 100 & from & $\mathrm{H} 2$ & $\begin{array}{l}\text { MOZART }^{2} \text {, zero volcanic aerosols, } \\
\text { time invariant land surface cover types, } \\
\text { seasonal varying solar irradiance }\end{array}$ \\
\hline B1 & 300 & & & & $\begin{array}{l}\text { Same as A1FI, but all forcing agents } \\
\text { were held constant after } 2100\end{array}$ \\
\hline
\end{tabular}

${ }^{1}$ Referred to GFDL as CM2.1U_Control-1860_D4. This scenario simulated the pre-industrial period.

${ }^{2}$ MOZART = Global Atmospheric Chemistry Climate Model.

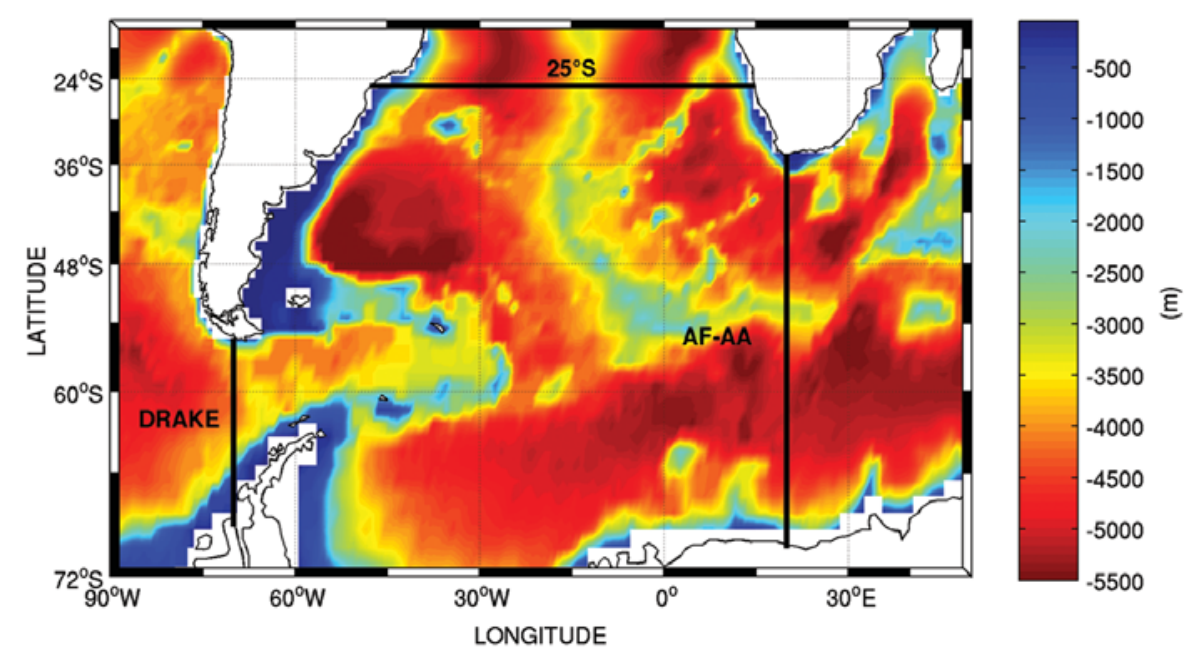

Figure 1 - Map of the South Atlantic Ocean with the locations of the monitored sections and the bathymetry used to run the CM2.1.

sections are widely used by the scientific community to estimate and monitor the aforementioned ocean transports.

The years 2050 and 2100 were chosen to highlight the volume and heat transports changes for the climate change scenarios. This is based on the integrated volume transport in the Drake's and AF-AA's water column time series for the A1FI and B1 scenarios (Figs. 2A and 2B). These two time series present the same behavior and the volume transports have the same order of magnitude, conserving the mass. The gray bars mark the moment when the volume transport reaches a new equilibrium. This moment may be considered a 'tipping point'. Also shown in Figure $2 \mathrm{C}$ is the integrated volume transport time series for the $25^{\circ} \mathrm{S}$. For this figure, the volume transport becomes negative at the beginning and end of the time series, meaning that, for these periods, the SA is exporting less heat northward which reflects changes in the water column as described on subsection 'Volume Transport'.

\section{RESULTS}

\section{Volume Transport}

The VT analyses were calculated through the integrated velocity profile through the zonal or meridional section and are associated with the currents flow. The A1FI and B1 climate change scenarios 2050 and 2100 years are highlighted as well as the $\mathrm{H} 2$ climate scenario 2000 year. Additionally, the anomalies provide a dynamic view of the transports.

Table 3 and Table 4 display the volume transport values integrated over the water column for the three climate change scenarios during 2000, 2050 and 2100 and their variances, respectively. It is observed that the Drake and AF-AA VTs associated with the AACC flow eastward, which is in agreement with the scientific literature (Rintoul, 1991; Tomczak \& Godfrey, 1994; Ganachaud \& Wunsch, 2000; Assad et al., 2009; Talley et al., 2011). Also, their values on the year 2000 are consistent with 

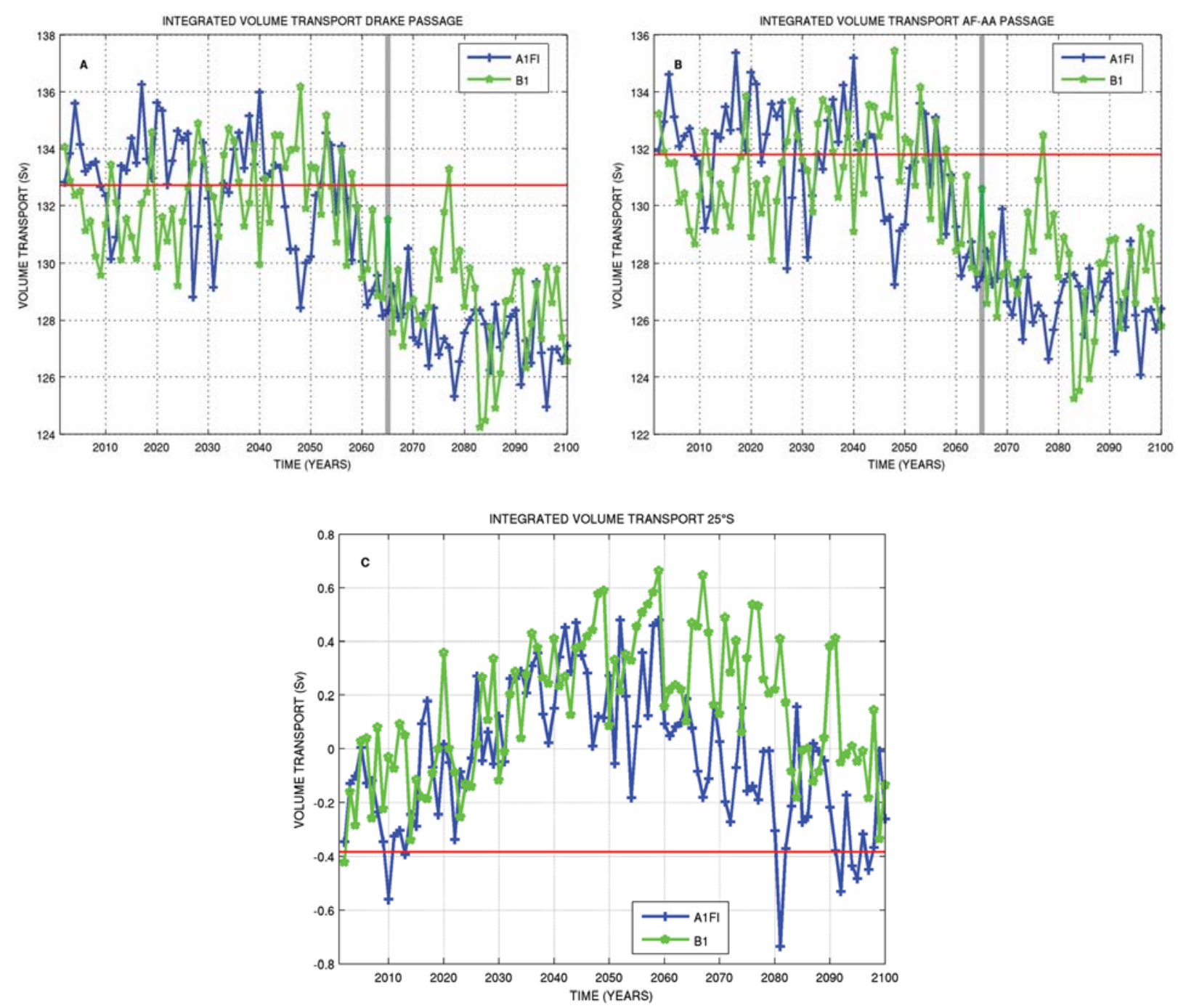

Figure 2 - The volume transport time series for the A) Drake; B) AF-AA; and C) $25^{\circ} \mathrm{S}$ sections integrated over the water column. The A1FI scenario is depicted in a + symbol line, whereas the B1 scenario is depicted in a - symbol line. The dashed line represents the mean volume transport for the year 2000 of the climate experiment. The gray bars represent the moment of change in the volume transport.

previous works (Table 1). Additionally, these transports decrease continuously until 2100 in the A1FI scenario. For B1, the transports increase from 2000 to 2050 but at the end this sections experiment the VT decreases for B1.

The decrease at the end of the experiments is $4.47 \%$ in Drake and $4.33 \%$ in AF-AA for the A1FI scenario. For the B1 scenario, the decrease is $5.83 \%$ in Drake and $5.70 \%$ in AF-AA. Notably, the observed changes in both sections have the same order of magnitude, obeying the Law of Mass Conservation. This behavior is expected because, as a coupled climate model, it represents the mass and energy exchanges between its components.

In the $25^{\circ} \mathrm{S}$ section, the VT integrated in the water column has a southward flow in the year 2000, which can be attributed to the NADW flow (Table 3). The NADW transports large amounts of NA water to the SA (Peterson \& Stramma, 1991; Stramma \& England, 1999). At the year 2000, the VT value is in agreement with previous works close to the $25^{\circ} \mathrm{S}$ parallel. In the A1FI scenario, the VT decreases from the year 2000 to 2050 and subsequently increases in 2100 . For the B1 scenario, the flow direction reverses in 2050. Specifically, the flow direction in 2000 was southward and became northward in 2050. In 2100, the flow is reversed again, flowing back southward. At the end of the experiments, the flow increases $28.94 \%$ for the A1FI scenario and decreases $28.94 \%$ for the B1 scenario.

These results reflect intensity variations in the water mass flows along the section's water column, each with a different flow 
Table 3 - The VT and HT values in 2000 (H2), 2050 and 2100 (A1FI and B1) in Sv and PW, respectively. ${ }^{2}$

\begin{tabular}{|c|c|c|c|c|c|c|c|c|c|}
\hline & \multicolumn{3}{|c|}{2000} & \multicolumn{3}{|c|}{2050} & \multicolumn{3}{|c|}{2100} \\
\hline & Drake & AF-AA & $25^{\circ} \mathrm{S}$ & Drake & AF-AA & $25^{\circ} \mathrm{S}$ & Drake & AF-AA & $25^{\circ} \mathrm{S}$ \\
\hline \multicolumn{10}{|c|}{ Volume transport in Sv $\left(1 \mathrm{~Sv}=10^{6} \mathrm{~m}^{3} \mathrm{~s}^{-1}\right)$} \\
\hline $\mathrm{H} 2$ & 132.73 & 131.79 & -0.38 & - & - & - & - & - & - \\
\hline $\mathrm{A} 1 \mathrm{Fl}$ & - & - & - & 132.37 & 131.32 & -0.05 & 126.80 & 126.08 & -0.49 \\
\hline B1 & - & - & - & 133.33 & 132.23 & 0.33 & 124.99 & 124.28 & -0.11 \\
\hline \multicolumn{10}{|c|}{ Heat transport in PW $\left(1 \mathrm{PW}=10^{15} \mathrm{~W}\right)$} \\
\hline $\mathrm{H} 2$ & 1.55 & 1.42 & 0.72 & - & - & - & - & - & - \\
\hline $\mathrm{A} 1 \mathrm{Fl}$ & - & - & - & 1.64 & 1.61 & 0.73 & 1.93 & 1.86 & 0.60 \\
\hline B1 & - & - & - & 1.63 & 1.62 & 0.61 & 1.72 & 1.73 & 0.53 \\
\hline
\end{tabular}

aThe positive values in the Drake and AF-AA sections indicate eastward flow and negative values indicate westward flow. The positive values at $25^{\circ} \mathrm{S}$ indicate northward flow and negative values indicate southward flow.

Table 4 - The VT and HT variances from Table 3.

\begin{tabular}{|c|c|c|c|c|c|c|c|c|c|}
\hline & \multicolumn{3}{|c|}{2000} & \multicolumn{3}{|c|}{2050} & \multicolumn{3}{|c|}{2100} \\
\hline & Drake & AF-AA & $25^{\circ} \mathrm{S}$ & Drake & AF-AA & $25^{\circ} \mathrm{S}$ & Drake & AF-AA & $25^{\circ} \mathrm{S}$ \\
\hline \multicolumn{10}{|c|}{ Volume transport in Sv } \\
\hline $\mathrm{H} 2$ & \pm 23.53 & \pm 23.81 & \pm 0.09 & - & - & - & - & - & - \\
\hline $\mathrm{A} 1 \mathrm{FI}$ & - & - & - & \pm 39.38 & \pm 42.43 & \pm 0.21 & \pm 41.99 & \pm 45.81 & \pm 0.35 \\
\hline $\mathrm{B} 1$ & - & - & - & \pm 36.08 & \pm 39.13 & \pm 0.13 & \pm 20.52 & \pm 23.56 & \pm 0.33 \\
\hline \multicolumn{10}{|c|}{ Heat transport in PW } \\
\hline $\mathrm{H} 2$ & \pm 0.00 & \pm 0.02 & \pm 0.03 & - & - & - & - & - & - \\
\hline $\mathrm{A} 1 \mathrm{FI}$ & - & - & - & \pm 0.00 & \pm 0.01 & \pm 0.02 & \pm 0.00 & \pm 0.02 & \pm 0.05 \\
\hline B1 & - & - & - & \pm 0.00 & \pm 0.02 & \pm 0.03 & \pm 0.00 & \pm 0.02 & \pm 0.02 \\
\hline
\end{tabular}

and direction pattern. Thus, the weakening and strengthening of the water mass flows affect the integrated VT intensity and direction. This behavior is better observed through Figure 3, the velocity profile at $25^{\circ} \mathrm{S}$ for the year 2000 of the climate experiment and Figures 4A to 4F, the 2050-2000, 2050-2100 and 2100-2000 velocity profile anomalies, respectively, of the A1FI and $\mathrm{B} 1$ scenarios.

The features of greater intensity throughout the water column are associated with the western boundary flows (Fig. 3). According to Rintoul (1991); Stramma \& England (1999); Silveira et al. (2000) and Silveira et al. (2004), four main water masses influence the western boundary current system of the region. They are the Tropical Water (TW) - formed on the Tropical region of the AO by intense warming and evaporation - and South Atlantic Central Water (SACW) flowing southward, - originated mainly at the Brazil-Malvinas Confluence (BMC) (Gordon, 1981), but part of it may enter the SA by the AF-AA Passage from the Indian Ocean - which forms the Brazil Current (BC), the northwardflowing AAIW, - originated on the east part of the Pacific Ocean and on the Weddell Sea (Tomczak \& Godfrey, 1994; Clarke et al., 2001) and brought to the SA through the Drake Passage - which forms the Intermediate Western Boundary Current (IWBC) and the southward-flowing NADW, which transports large volumes of water and forms the DBC. At greater depths, the AABW - in the SA is originated from the Weddell Sea (Speer \& Zenk, 1993; Tomczak \& Godfrey, 1994; Clarke et al., 2001) flows northward.

In the region closest to the American continents, a cell of $\mathrm{BC}$ formed by TW and the SACW flows southward along the Brazilian coast from the surface to a depth near 500 meters. Below the $\mathrm{BC}$, the IWBC (represented by the AAIW) flows northward. Below the IWBC, the DBC (represented by the NADW) flows southward. Below the NADW, the AABW flows northward.

In addition to these flows, we highlight the flows comprising the remainder of the section and the adjacent regions of the African continent at depths from the surface to approximately 1,000 meters. According to Stramma \& England (op. cit.), the flow moving to the north occupying most of the section from the surface to a depth close to 1,000 meters is associated with the 


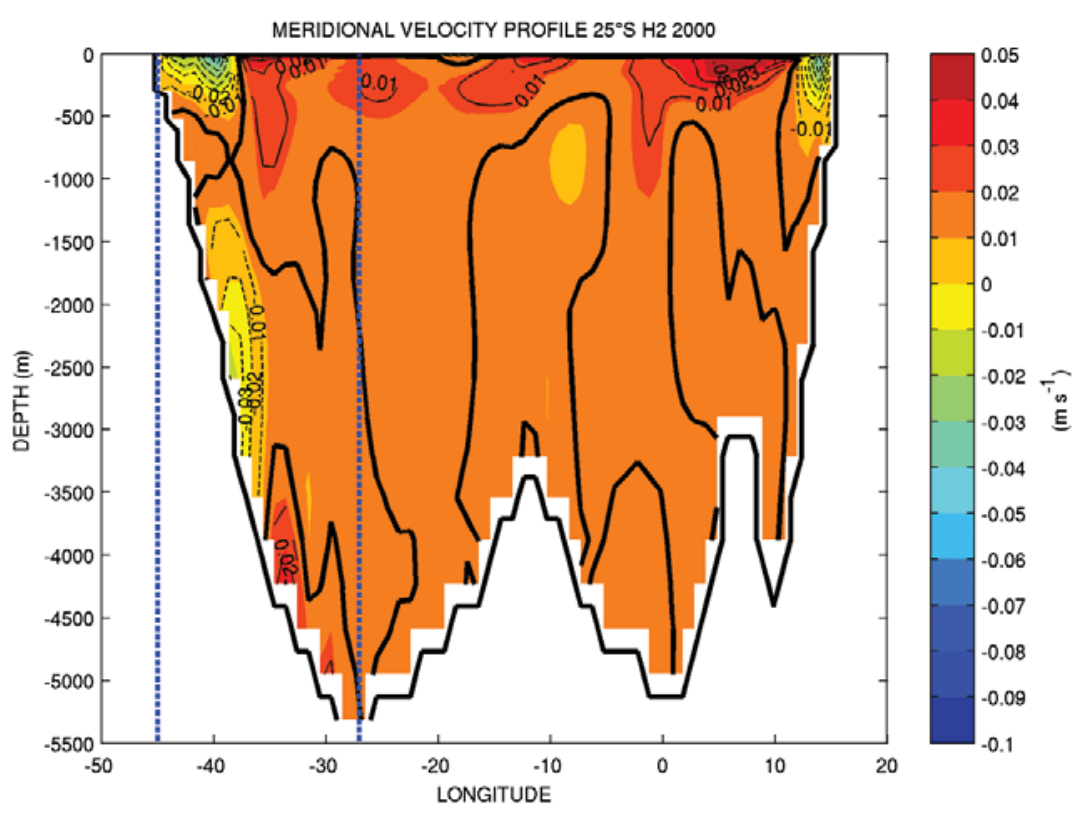

Figure 3 - The velocity profile of the $25^{\circ} \mathrm{S}$ section in the year 2000 for the climate experiment. The thicker lines represent locations of zero velocity.

Benguela Current $(\mathrm{BgC})$. To the east of this current, there is an intense and narrow flow to the south that occupies the surface to a depth of approximately 500 meters. This flow may be associated with the flow that emanates from the Angola Gyre and moves southward toward the $30^{\circ} \mathrm{S}$ parallel, which recirculates and contributes to the Southern South Equatorial Current (SSEC) (see Stramma \& England's (op. cit.), Fig. 3). Gordon \& Bosley (1991), through hydrographic data, identified this tropical Gyre centered near $13^{\circ} \mathrm{S}$ and $5^{\circ} \mathrm{E}$ and characterized it as a quasistationary climatic feature.

Figure 5 represents the temperature-salinity diagram for the region localized on the $25^{\circ} \mathrm{S}$ latitude between the longitudes $45^{\circ} \mathrm{W}$ and $27^{\circ} \mathrm{W}$ (the highlighted region in Fig. 3). The water masses mentioned above are highlighted on this figure following the thermohaline index presented on Table 5. It can be seen that the T-S diagram exhibits the form of all the water masses mentioned above, indicating that they are, indeed, present in the western boundary region of the $25^{\circ} \mathrm{S}$ section. However, through the thermohaline index, it can be seen that the AABW is not represented in the water column, which indicates that it suffered changes in its index.

To identify and quantify the changes in the velocity profile of the $25^{\circ} \mathrm{S}$ section of the climate change scenarios in relation to the climate experiment, the anomalies of these flows were calculated according to Eq. (3). The anomalies represent an increase or decrease of the meridional velocity of this section relative to var- ious times. Additionally, we estimated the anomalies of the year 2100 compared to 2050 for both climate change scenarios.

For flows moving northward (positive values), positive anomalies indicate an increased velocity (red color), whereas negative anomalies indicate a decreased velocity (blue color). In contrast, for flows moving southward (negative values), negative anomalies indicate an increased velocity (blue color) and positive anomalies indicate deceleration (red color).

The A1FI 2050 anomaly for the climate change experiments is depicted in Figure 4A. An intensive reduction of the BC cell flow and intensification of the northward AAIW cell flow on the western boundary, along with a reduction of the NADW flows, are apparent. As a result, the southward VT integrated in the water column for the A1FI scenario weakened (Table 3). In Figure 4B, the B1 2050 anomaly - the intense deceleration of the southward $B C$ cell and positive anomalies of the AAIW, NADW and AADW, resulting in decrease on the southward flow and increase on the northward flows, caused the flow direction change of the integrated transport for the B1 experiment (Table 3), although a slight decrease of the $\mathrm{BgC}$ northward flow and increase of the southward $\mathrm{BC}$ flow closer to the coast is observed. The diminished strength on the $\mathrm{BC}$ may dislocate the $\mathrm{BMC}$ northward, once the Malvinas Current $(\mathrm{MC})$ will progress further north and then the SACW formation region will shift northward.

For 2100 anomaly for the A1FI experiment (Fig. 4C), the increase of the southward VT integrated in the water column on 

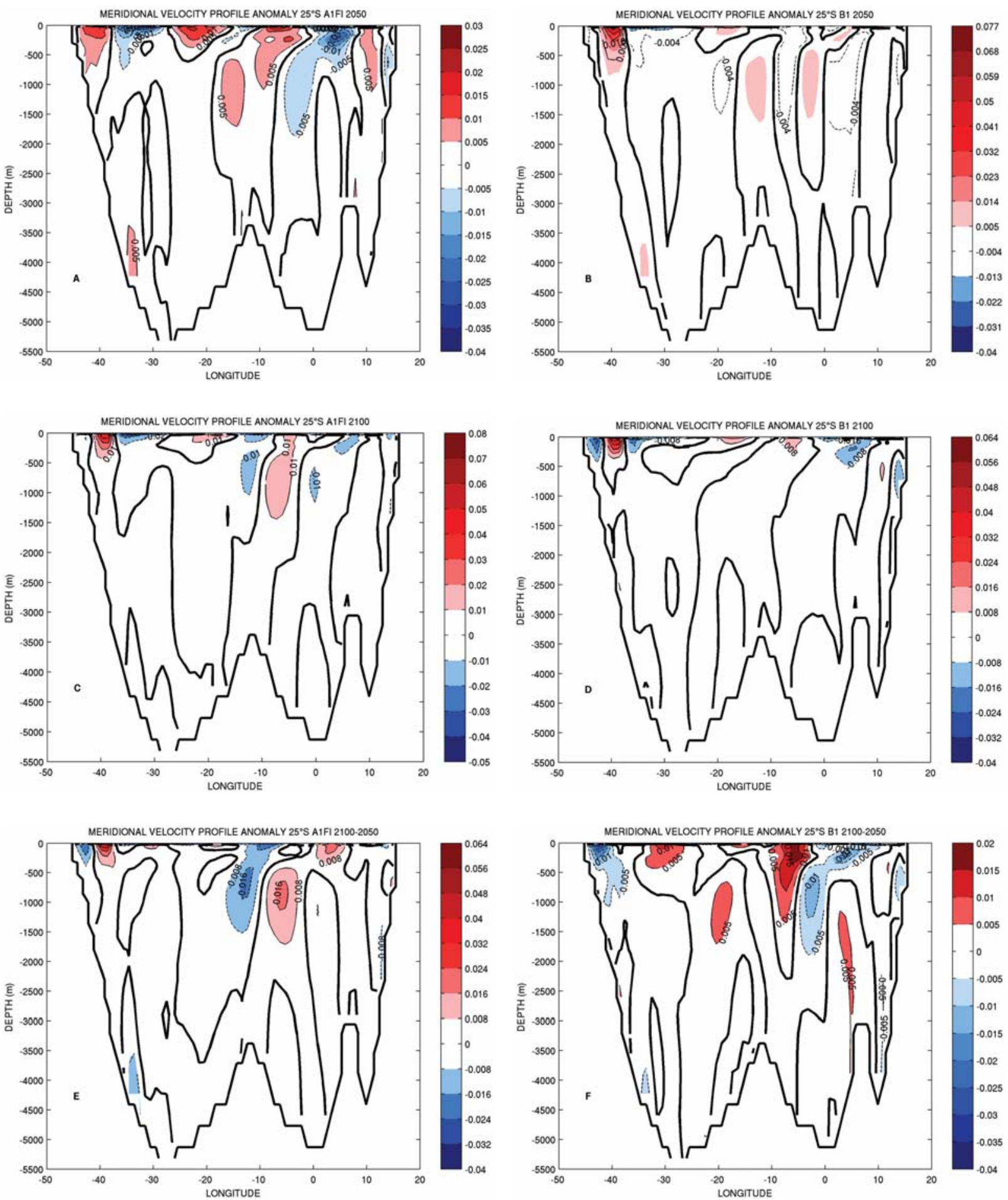

Figure 4 -A) Velocity anomaly profiles in the $25^{\circ} \mathrm{S}$ section for A) 2050 anomaly for A1Fl and B) 2050 anomaly for B1. C) 2100 anomaly for A1FI and D) 2100 anomaly for B1. E) 2100-2050 anomaly A1FI and F) 2100-2050 anomaly for B1. The thicker lines represent locations of zero velocity. 


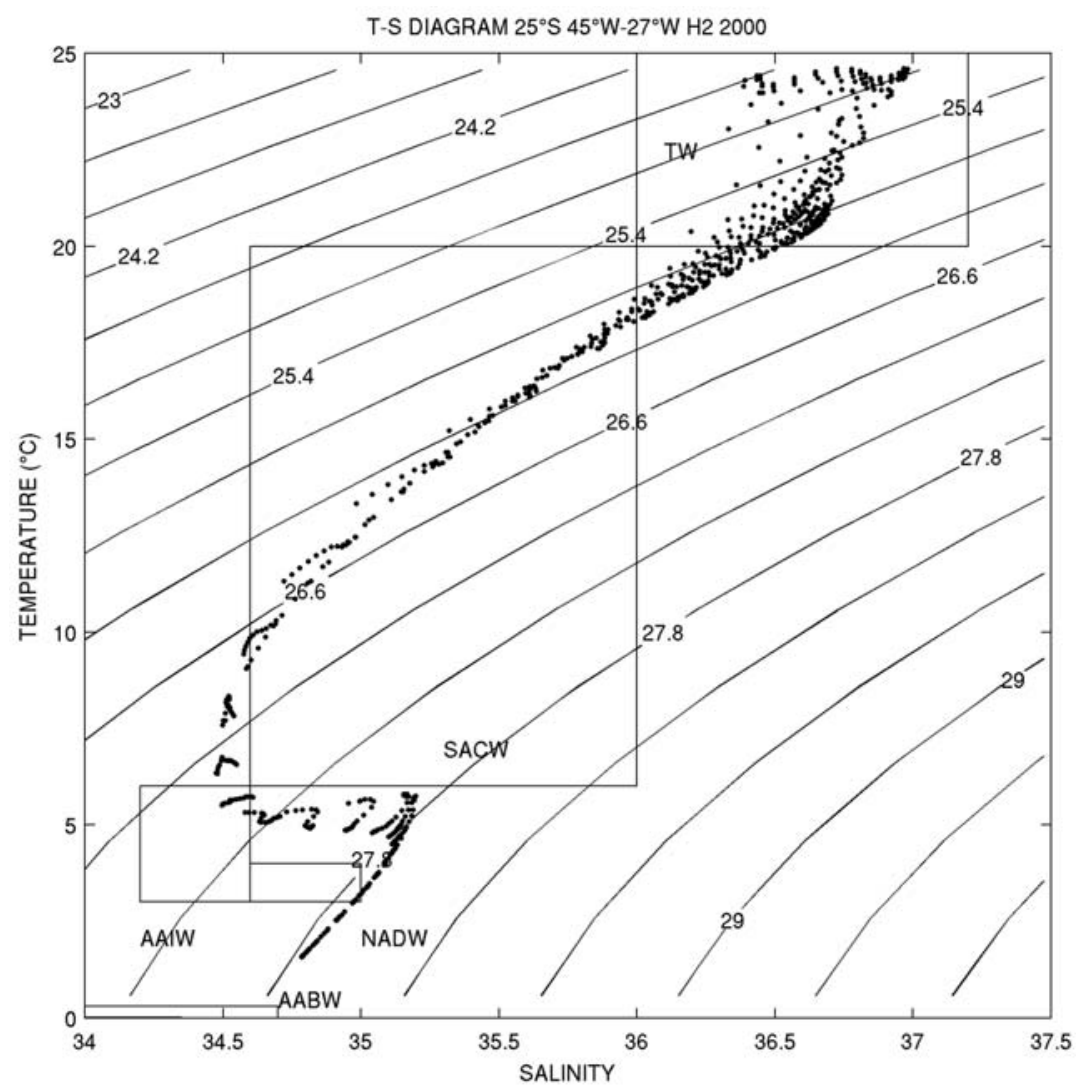

Figure $\mathbf{5}$ - Temperature-salinity diagram with the water masses highlighted through box representation for the $25^{\circ} \mathrm{S}$ latitude, between $35^{\circ} \mathrm{W}$ and $25^{\circ} \mathrm{W}$ for the year 2000 of the $\mathrm{H} 2$ scenario. The slanted lines represent the isopicnals from the temperature and salinity ranges.

Table $\mathbf{5}$ - Water masses thermohaline indexes found in the SA.

\begin{tabular}{|c|c|c|c|c|}
\hline $\begin{array}{l}\text { Water } \\
\text { mass }\end{array}$ & Reference & $\begin{array}{c}\text { Temperature } \\
\left({ }^{\circ} \mathrm{C}\right)\end{array}$ & $\begin{array}{c}\text { Salinity } \\
\text { (ups) }\end{array}$ & $\begin{array}{l}\text { Depth } \\
\text { (m) }\end{array}$ \\
\hline TW & Emilson (1961) & $>20^{\circ}$ & 36.0 & $0-200$ \\
\hline SACW & Miranda (1985) & $6^{\circ}<\mathrm{T}<20^{\circ}$ & $34.6<\mathrm{S}<36.0$ & $200-900$ \\
\hline AAIW & $\begin{array}{c}\text { Sverdrup et al. } \\
\text { (1942) }\end{array}$ & $3^{\circ}<\mathrm{T}<6^{\circ}$ & $34.2<\mathrm{S}<34.6$ & $\sim 1000$ \\
\hline NADW & $\begin{array}{c}\text { Silveira et al. } \\
(2000)\end{array}$ & $3^{\circ}<\mathrm{T}<4^{\circ}$ & $34.6<\mathrm{S}<35.0$ & $1500-3000$ \\
\hline AABW & $\begin{array}{c}\text { American } \\
\text { Meteorological } \\
\text { Society } \\
\text { Tomczak \& } \\
\text { Godfrey (1994) }\end{array}$ & $\mathrm{T}<0.3^{\circ}$ & $\mathrm{S}<34.7$ & $>4000$ \\
\hline
\end{tabular}

the western boundary may have been caused by the increase of the western part of the BC flow and decrease of the AAIW and AABW flows. Additionally, an increase of the southward flow to the east of the $\mathrm{BgC}$ is apparent. Once the $\mathrm{BC}$ strengthens, the
BMC is shifted southward, the Malvinas Current can't progress much further and less AAIW enters the SA.

For the 2100 B1 experiment anomaly (Fig. 4D), the reversal of the flow direction southward may have been concomitantly 
caused by the increase of the western part of the $\mathrm{BC}$ flow and the decrease of the AAIW, AABW and BgC flows. Additionally, a decrease of the NADW flow and the flow to the east of the BgC is observed, which prevents the southward flow from reaching the intensity observed in 2000 (Table 3). The decrease of the southward VT on $25^{\circ} \mathrm{S}$ may have an impact on the VT exported from the SA through the AF-AA Passage, once the NADW is the mainly responsible for the southward flow (Stramma \& England, 1999).

Between 2050 and 2100, for the A1FI experiment (Fig. 4E), the intensification of the southward flow of the integrated VT was mainly caused by the decrease of the AABW and part of the BgC flow, the increase of the $B C$ flow on its western part, although there is a decrease on the east part, and the increase of the flow to the east of the $\mathrm{BgC}$, despite the decrease of most of the NADW flow. For the B1 experiment (Fig. 4F), although there is a weakening on the NADW flow and on flow to the east of the $\mathrm{BgC}$, an intense increase of the BC flow and a weakening of the AAIW flow provided the shift of the VT back southward.

\section{Heat Transport}

The HT analyses were calculated through the integrated velocity and temperature profile through the zonal or meridional section related to the amount of heat carried by the currents. The same climate and climate change scenarios are displayed here. Figure 6 shows the integrated $\mathrm{HT}$ at each of the sections.

The HTs in Drake and AF-AA (Figs. 6A and 6B) flow to the east, associated with the AACC flow. At the year 2000, the HT values for these sections agree with previous works (Table 1). An increase of the integrated HT occurs continuously until 2100. The increase at the end of the experiments is approximately $24.52 \%$ in Drake and $30.99 \%$ in AF-AA for the A1FI scenario and $10.97 \%$ in Drake and $21.83 \%$ in AF-AA for the B1 scenario (Table 3). Despite the decreasing VT at the end of the experiments, the HT has the opposite behavior. This is related to the greater amount of heat available to be transported, despite the evidence of a potential AACC weakening.

At the $25^{\circ} \mathrm{S}$ section, for the entire time series, the $\mathrm{HT}$ is northward reinforcing the role played by the SA exporting heat for the NA. For the year 2000, the HT value is sometimes overestimated when compared to previous works (Table 1), but other times the value is in good agreement with them. It is important to observe that despite being northward for the entire time series, the HT decreases for both scenarios, with very high fluctuations, which can be observed by the distance between the mean heat transport for the year 2000 of the climate experiment and the climate change scenarios (A1FI and B1) values and also on Table 3. This decrease results in reduced heat transfer to the NA, which may cause changes in the NADW area and rate formation (Schmitz \& McCartney, 1993). The decrease at the end of the experiments is approximately $16.67 \%$ for the A1FI and $26.39 \%$ for the B1.

Taking the A1FI scenario as an example, if $0.12 \mathrm{PW}$ is being left behind by the $25^{\circ} \mathrm{S}$ section and only extra $0.06 \mathrm{PW}$ is leaving the SA through the AF-AA section, the remainder of heat must be warming up the $S A$. In fact, that is exactly what happens. Figure 7 shows the integrated stored heat in the oceanic volume among the three sections (Fig. 1). For both climate change scenarios, the stored heat is observed to increase continuously until the end of the time series. At the end, there is an increase, for the A1FI scenario, of approximately $0.74 \mathrm{TW}\left(1 \mathrm{TW}=10^{12} \mathrm{~W}\right)$. The differences on the magnitude between the $\mathrm{HT}$ and the Stored Heat indicate that the air-sea interactions are trying to achieve balance. At the end, the increase is approximately $27.89 \%$ and $13.61 \%$ for the A1FI and B1 scenarios, respectively.

\section{DISCUSSIONS}

This research aimed to analyze the HT and VT in three sections of the South Atlantic Basin associated with the A1FI and B1 climate change scenarios. The results of the CM2.1 were used in annual averages from 2001 until 2100. The HT and VT results of the climate scenario $(\mathrm{H} 2)$ were consistent with most of the previously reported estimates with order of magnitude for the VT of $10^{2}$ for the Drake and AF-AA sections and $10^{-1}$ for the $25^{\circ} \mathrm{S}$ section. For the $\mathrm{HT}$, the order of magnitude was $10^{0}$ for the Drake and AF-AA sections and $10^{-1}$ for the $25^{\circ} \mathrm{S}$ section. At the end of both climate change experiments, the VT on Drake and AF-AA passages decreased, while the HT for these sections increased. For the $25^{\circ} \mathrm{S}$ section, the VT increases at the end of the experiment for the A1FI, while it decreases for the B1. For the HT in this section, decrease for both climate change experiments is observed.

Figure 8A displays the 2050 integrated VT anomalies for the $\mathrm{A} 1 \mathrm{Fl}$ and $\mathrm{B} 1$ experiments. The climate experiment indicates the direction and value of the resulting integrated transport in the water column for the year 2000. The increase of the transport in the climate change experiments is shown by the arrow in the same direction of the climate experiment, while the decrease is indicated with an arrow in the opposite direction. The values quantify the increase or decrease of this variation.

In the Drake and AF-AA sections, the integrated transports flow to the east, which is in agreement with the scientific literature (Rintoul, 1991; Ganachaud \& Wunsch, 2000; Assad et al., 2009). However, a decrease for the A1FI experiment and an increase for the B1 experiment are observed. In the $25^{\circ} \mathrm{S}$ section, the integrated VT decreases for both experiments. 

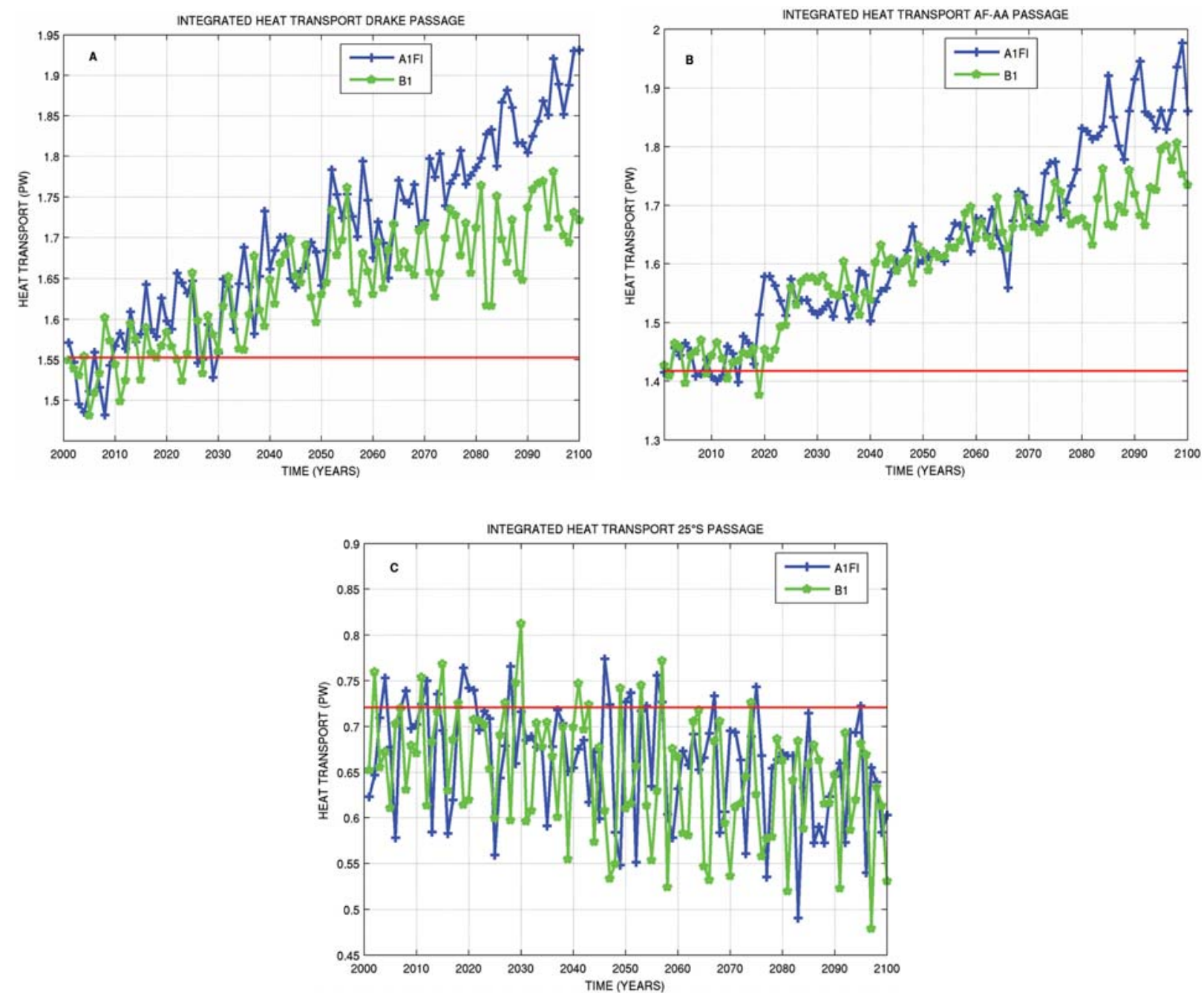

Figure 6 - The heat transport time series for the A) Drake, B) AF-AA and C) $25^{\circ} \mathrm{S}$ sections integrated over the water column. The A1FI scenario is depicted in a + symbol line, whereas the B1 scenario is depicted in a symbol line. The dashed line represents the mean heat transport for the year 2000 of the climate experiment.

Figure 8B displays the 2100 VT anomalies for the A1FI and B1 experiments. In the Drake and AF-AA sections, a decrease in the resulting VTs for both experiments are observed. This decrease may be strongly linked to changes in the AABW flows in this region. Because the AABW can be transported to the east or west (Cunningham et al., 2003), the decrease in the VT in these sections may be influenced by changes in the flow patterns of this water mass. These flow pattern changes stem from changes in the formation process due to the atmospheric $\mathrm{CO}_{2}$ fluctuations characteristic of the climate change scenarios used. In the $25^{\circ} \mathrm{S}$ section, an increase in the VT for the A1FI experiment and a decrease for the B1 experiment are observed. As mentioned previously, this result may be associated with variations in the intensity of the water mass flows in this section.

Figures $8 \mathrm{C}$ and $8 \mathrm{D}$ represent the HT anomalies in 2050 and
2100, respectively, for the A1FI and B1 experiments. In the Drake and AF-AA sections, as observed previously, the integrated HTs flow eastward and increase for both experiments and both anomalies. This behavior is related to an increase basin temperature, as seen previously by Lee et al. (2011).

In the $25^{\circ} \mathrm{S}$ section, for the B1 scenario, a decrease is observed in the northward $\mathrm{HT}$ flow for both anomalies. For the A1FI scenario, a slight increase is observed in the 2050 anomaly, but this increase cannot be considered once the variance surpasses the magnitude of the observed change. The behavior of the A1FI scenario for this anomaly can be interpreted as with no change in the HT. For the 2100 anomaly, there is a decrease of the northward flow.

Here, we highlight some trends in the results. For the B1 experiment in 2050, the VT increases in the Drake section and 


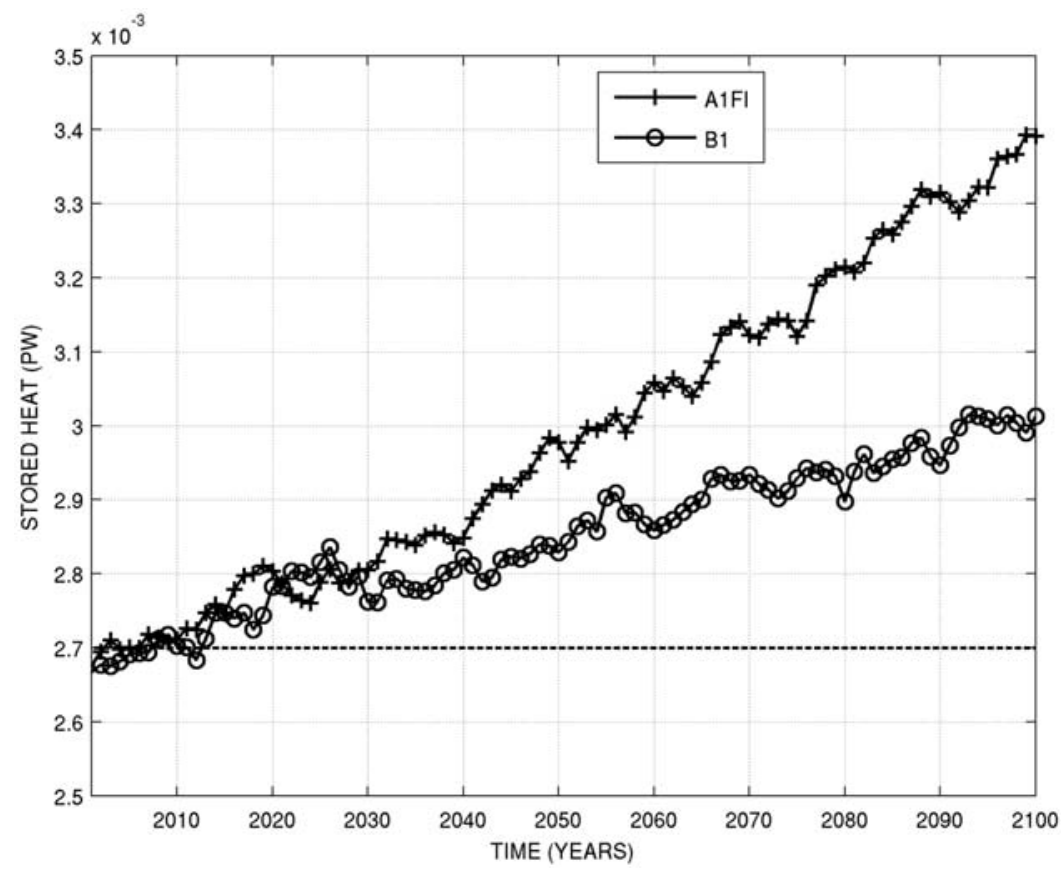

Figure 7 - The stored heat time series between the monitored sections integrated in the water column. The A1FI scenario is depicted in blue, whereas the B1 scenario is depicted in green. The red line represents the mean volume transport for the year 2000 of the climate experiment.

at $25^{\circ} \mathrm{S}$ the flow reverses, indicating a possible connection between the flow that enters the SA and the flow directed northward towards the NA. This connection may also be observed for the same scenario in 2100, when the VT in the Drake and AF-AA sections decrease and at $25^{\circ} \mathrm{S}$, it flows back to the south. For the A1FI scenario in 2100, the Drake and AF-AA sections VT decrease and the $25^{\circ} \mathrm{S}$ section VT increases southward.

It is also observed that the integrated 2050 VT flow at $25^{\circ} \mathrm{S}$ for the B1 scenario is reversed, whereas the integrated HT decreases. This result indicates that the water column portion that carries heat towards the NA is not the portion that strengthens in 2050. Similarly, for the A1FI scenario in the same section and year, the VT decreases and the HT does not change, indicating that the portion that transports the heat towards the NA strengthened or did not change.

The differences between the climate change scenarios behavior are quite distinguishable. On the Drake and AF-AA passages, the amplitude of $\mathrm{HT}$ increase is smaller for the B1 scenario than for the A1FI, based on the HT time series (Fig. 6). The scenarios have an opposite behavior for the $25^{\circ} \mathrm{S}$ section. On this section, the amplitude of decrease is greater for the B1 scenario. These sorts of differences between the climate change scenarios behaviors are also clear for the VT time series (Fig. 2). The fact that the $\mathrm{B} 1$ scenario stabilizes its $\mathrm{CO}_{2}$ concentrations at the end of the study period and the A1FI scenario does not, seems to be the key for the differences seen between them. Also these differences are responsible for changing circulation patterns, hence having the ability to act on decision making.

The analysis revealed different behaviors for the VT and HT and connections between the sections evaluated. Given the high complexity of the climate system, it will be interesting to analyze the other tipping point in 2080 (Figs. 2A and 2B) and the hole SA basin.

\section{CONCLUSIONS}

This research analyzed the heat and volume transports changes in three sections of the South Atlantic Basin associated with two climate change scenarios. With the results presented here, it was possible to obtain a preliminary vision of the altered greenhouse gas emissions influence on the integrated HT and VT in the SA.

The integrated VTs in the Drake and AF-AA sections indicate that the AACC behavior is characterized by an eastward flow. The climate change scenario analysis for these sections conveyed a decrease near $5 \%$ for the $\mathrm{A} 1 \mathrm{FI}$ and $6 \%$ for the $\mathrm{B} 1$ at the end of the experiments. For the $25^{\circ} \mathrm{S}$ section in 2000 , the integrated VT has a southward flow, which may be associated mainly with the NADW flow on this region. However, other southward flows contribute to this resultant flow. For the climate change experiments, intensity and direction oscillations for the years 2050 and 2100 are apparent. These results are related to intensity variations 

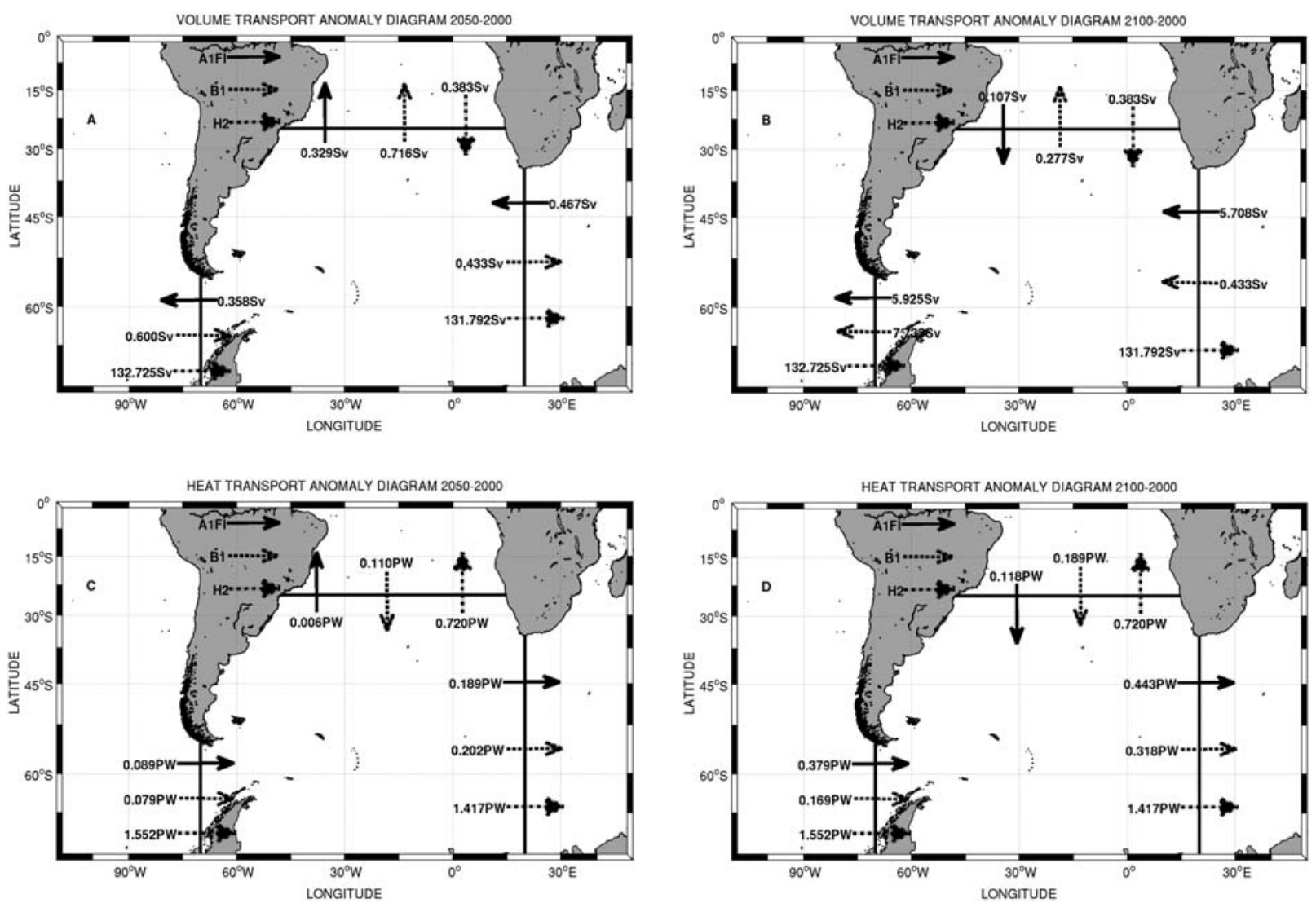

Figure 8 - A) The 2050 and B) The 2100 VT anomalies, in Sv. C) The 2050 and D) The 2100 HT anomalies for the A1FI and B1 scenarios. The climate experiment indicates the value and direction of the VT (HT) in 2000. Increases in the VT (HT) are illustrated with an arrow in the same direction as the climate. Decreases are illustrated with an arrow in the opposite direction. The values quantify the increase or decrease.

and oscillations of the currents and water masses comprising the water column of this section, which have different flow directions as illustrated in Figure 4. In the velocity profile anomalies of this section, despite the NADW transport of large amounts of water towards high latitudes in the SA, this water mass was not responsible for the integrated VT changes.

The integrated HTs for the Drake and AF-AA sections increase continuously. These increases are larger for the A1FI scenario in AF-AA, which may be related to the integrated HT decrease at $25^{\circ} \mathrm{S}$ at the end of the experiments. This decrease may have caused progressive heating in the region.

Based on the results, we conclude that at the end of the experiments, there is a decrease in the water supply at $25^{\circ} \mathrm{S}$ due to the integrated VT decrease in the Drake and AF-AA sections, despite the warmer water. As a consequence, the northward integrated HT flow decreases. This pattern is more intense for the B1 scenario. In fact, the 2100 VT in the Drake section of this scenario decreases more intensively than in the A1Fl. Consequently, the $\mathrm{HT}$ at the $25^{\circ} \mathrm{S}$ section also decreases more inten- sively for this scenario in 2100 . This process may cause altered patterns of formation in the NADW, which may trigger changes in the MOC and the global climate patterns as Zheng \& Giese (2009) suggested that the ocean heat transport variability is determined by the MOC.

\section{ACKNOWLEDGEMENTS}

I would like to thank the Programa de Formação de Recursos Humanos (PFRH) for encouraging knowledge development, the GFDL for make available the CM2.1 results and the Laboratório de Métodos Computacionais em Engenharia (LAMCE) for supporting this research.

\section{REFERENCES}

ASSAD LPF. 2011. ENSO-Type Wind Stress Field Influence over Global Ocean Volume and Heat Transports. In: HANNACHI A (Ed.). Climate Variability - Some Aspects, Challenges and Prospects. Rijeka, Croatia: InTech, pp. 99-120. 
ASSAD LPF, TORRES Jr AR, ARRUDA WZ, MASCARENHAS Jr A \& LANDAU L. 2009. Volume and Heat Transports in the World Oceans from an Ocean General Circulation Model. Brazilian Journal of Geophysics, 27(2): 181-194.

BIASTOCH A, BÖNING CW, SCHWARZKOPF FU \& LUTJEHARMS JRE. 2009. Increase in Agulhas leakage due to poleward shift of Southern Hemisphere westerlies. Nature, 462: 495-499.

BOLLMANN M, BOSCH T, COLIJN F, EBINGHAUS R, FROESE R, GÜSSOWK, KHALILIANS, KRASTELS, KÖRTZINGERA, LANGENBUCH M, LATIF M, MATTHIESSEN B, MELZNER F, OSCHLIES A, PETERSEN S, PROELBA, QUAAS M, REICHENBACH J, REQUATE T, REUSCH T, ROSENSTIEL P, SCHMIDT JO, SCHROTTKE K, SICHELSCHMIDT H, SIEBERT U, SOLTWEDEL R, SOMMER U, STATTEGGER K, STERR $H$, STURM R, TREUDE T, VAFEIDIS A, BERNEM $C$ van, BEUSEKOM J van, VOSS R, VISBECK M, WAHL M, WALLMANN $K$ \& WEINBERGER $F$. 2010. World Ocean Review. $1^{\text {st }}$ ed. Hamburg: Maribus, ISBN 978-386648-012-4. $236 \mathrm{pp}$.

BROECKER WS. 1991. The Great Ocean Conveyor. Oceanography, 4(2): 79-89.

BROECKER WS. 1997. Thermohaline Circulation, the Achilles Heel of our Climate System: Will Man-Made $\mathrm{CO}_{2}$ Upset the Current Balance? Science, 278: 1582-1588. doi: 10.1126/science.278.5343.1582.

CAMPOSE, BUSALACCHI A, GARZOLIS, LUTJEHARMS J, MATANO R, NOBRE P, OLSON D, PIOLA A, TANAJURA C \& WAINER I. 1999. The South Atlantic and climate. In: The Ocean Observing System for Climate, OCEANOBS99, St. Raphael, France. 1999. 20 pp.

CLARKE A, CHURCH J \& GOULD J. 2001. The Ocean and Climate: Ocean Processes and Climate Phenomena. In: SIEDLER G, CHURCH J \& GOULD J. (Eds.). Ocean Circulation and Climate: Observing and Modelling the Global Ocean. London, San Diego: Academic Press, pp. 11-30.

CUNNINGHAM SA, ALDERSON SG, KING BA \& BRANDON MA. 2003. Transport and variability of the Antarctic Circumpolar Current in Drake Passage. J. Geophys. Res., 108(C5): 8084. doi: 10.1029/2001JC001147.

DELWORTH TL, BROCCOLI AJ, ROSATI A, STOUFFER RJ, BALAJI V, BEESLEY JA, COOKE WF, DIXON KW, DUNNEJ, DUNNE KA, DURACHTA JW, FINDELL KL, GINOUXP, GNANADESIKAN A, GORDON CT, GRIFFIES SM, GUDGEL R, HARRISON MJ, HELD IM, HEMLER RS, HOROWITZ LW, KLEIN SA, KNUTSON TR, KUSHNER PJ, LANGENHORST MR, LEE H, LIN S, LU J, MALYSHEV SL, MILLY PCD, RAMASWAMY V, RUSSELL J, SCHWARZKOPF MD, SHEVLIAKOVA E, SIRUTIS JJ, SPELMAN MJ, STERN WF, WINTON M, WITTENBERG AT, WYMAN B, ZENG F \& ZHANG R. 2006. GFDL's CM2 Global Coupled Climate Models. Part I: Formulation and Simulation Characteristics. Journal of Climate, American Meteorological Society, 19: 643-674.

DONNERS J, DRIJFHOUT SS \& HAZELEGER W. 2005. Water mass transformation and subduction in the South Atlantic. Journal of Physical Oceanography, American Meteorological Society, 35: 1841-1860.
EVANS DL \& SIGNORINI SS. 1985. Vertical Structure of Brazil Current. Nature, 315(6014): 48-50.

GANACHAUD A \& WUNSCH C. 2000. Improved Estimates of Global Ocean Circulation, Heat Transport and mixing from Hydrographic Data. Nature, 408: 453-457.

GARZOLI SL \& BARINGER M0. 2007. Meridional heat transport determined with expandable bathythermographs - Part II: South Atlantic transport. Deep-Sea Research, 54(8): 1402-1420.

GFDL. 2006a. CM2.1 experiments and metadata: CM2.1U_Control1860_D4. Available on: <http://nomads.gfdl.noaa.gov/CM2.X/CM2.1/ data/metadata/PIcntrl_sun1.html>. Access on: March 12, 2011.

GFDL. 2006b. CM2.1 experiments and metadata: CM2.1UD4_18602000-AllForc_H2. Available on: < http://nomads.gfdl.noaa.gov/CM2.X/ CM2.1/data/metadata/20C3M sun2.html>. Access on: May 14, 2011.

GFDL. 2006c. CM2.1 experiments and metadata: CM2.1U-H2_SresA1FI. Available on: <http://nomads.gfdl.noaa.gov/CM2.X/CM2.1/data/metadata/SRESA1FI sun1.html>. Access on: May 12, 2011.

GNANADESIKAN A, DIXON KW, GRIFFIES SM, BALAJI V, BARREIRO M, BEESLEY JA, COOKE WF, DELWORTH TL, GERDES R, HARRISON MJ, HELD IM, HURLIN WJ, LEE H, LIANG Z, NONG G, PACANOWSKI RC, ROSATI A, RUSSELL J, SAMUELS BL, SONG Q, SPELMAN MJ, STOUFFER RJ, SWEENEY CO, VECCHI G, WINTON M, WITTENBERG AT, ZENG F, ZHANG R \& DUNNE JP. 2006. GFDL's CM2 Global Coupled Climate Models. Part II: The Baseline Ocean Simulation. Journal of Climate, American Meteorological Society, 19: 675-697.

GORDON AL. 1981. South Atlantic thermocline ventilation. Deep-Sea Research, Part A, 28: 1239-1264.

GORDON AL. 2003. The Brawniest retroflection. Nature, 421: 904-905. GORDON AL \& BOSLEY KT. 1991. Cyclonic Gyre in the Tropical South Atlantic. Deep-Sea Research, 38(Suppl. 1): S323-S343.

GRASSL H. 2001. The Ocean and Climate: Climate and Oceans. In: SIEDLER G, CHURCH J \& GOULD J. (Eds.). Ocean Circulation and Climate: Observing and Modelling the Global Ocean. London, San Diego: Academic Press, pp. 3-10.

GRIFFIES SM, BÖNING C, BRYAN FO, CHASSIGNET EP, GERDES R, HASUMI H, HIRST A, TREGUIER A \& WEBB D. 2000. Developments in ocean climate modeling. Ocean Modelling, 2: 123-192.

GRIFFIES SM, GNANADESIKAN A, DIXON KW, DUNNE JP, GERDES R, HARRISON MJ, ROSATI A, RUSSELL JL, SAMUELS BL, SPELMAN MJ, WINTON M \& ZHANG R. 2005. Formulation of an ocean model for global climate simulations. Ocean Science, 1: 45-79.

GRIFFIES SM, HARRISON MJ, PACANOWSKI RC \& ROSATI A. 2008. A Technical Guide to MOM4 GFDL Ocean Group Technical Report No. 5. NOAA/Geophysical Fluid Dynamics Laboratory. Available on: <www.gfdl.noaa.gov> $>$. Access on: March 20, 2011.

HOUGHTON JT. 2004. Global Warming. $3^{\text {rd }}$ ed. New York: Cambridge University Press, ISBN 0-521-528747. 351 pp.

HOUGHTON JT. 2009. Global Warming. $4^{\text {th }}$ ed. New York: Cambridge University Press, ISBN 978-0-521-70916-3. 438 pp. 
LEE S, PARK W, SEBILLE E van, BARINGER MO, WANG C, ENFIELD DB, YEAGER SG \& KIRTMAN BP. 2011. What caused the significant increase in Atlantic Ocean heat content since the mid-20th century? Geophysical Research Letters, 38: 6 pp. doi: 10.1029/2011GL048856.

MKHANDI SH, VALIMBA P \& KIMARO TA. 2008. Development of Climate Change Scenarios. Pangani River Basin Flow Assessment. Pangani Basin Water Board, Moshi and IUCN Eastern and Southern Africa Regional Programme, 7: 53 pp.

PETERSON RG \& STRAMMA L. 1991. Upper-level circulation in the South Atlantic Ocean. Prog. Oceanog., 26: 1-73.

POND S \& PICKARD GL. 1983. Introductory Dynamical Oceanography. $2^{\text {nd }}$ ed. Pergamon Press Inc., New York, 349 pp. ISBN: 0750624965.

RINTOUL SR. 1991. South Atlantic Interbasin Exchange. Journal of Geophysical Research, 96(C2): 2675-2692.

SCHMITZ WJ \& McCARTNEY MS. 1993. On the North Atlantic Circulation. Reviews of Geophysics, 31(1): 29-49.

SILVEIRA ICA da, SCHMIDT ACK, CAMPOS EJD, GODOI SS \& IKED YA. 2000. Corrente do Brasil ao Largo da Costa Leste Brasileira. Brazilian Journal of Oceanography, 48(2): 171-183.

SILVEIRA ICA, CALADO L, CASTRO BM, CIRANO M, LIMA JAM \& MASCARENHAS AS. 2004. On the baroclinic structure of the Brazil Current - Intermediate Western Boundary Current system at $22^{\circ}-23^{\circ} \mathrm{S}$. Geophys. Res. Lett., 31, L14308. doi: 10.1029/2004GL020036.

SPEER KG \& ZENK W. 1993. The Flow of Antarctic Bottom Water into the Brazil Basin. Journal of Physical Oceanography, 23: 2667-2682.

STAMMER D, WUNSCH C, GIERING R, ECKERT C, HEIMBACH P, MAROTZKE J, ADCROFT A, HILL CN \& MARSHALL J. 2003. Volume, heat, and freshwater transports of the global ocean circulation 19932000, estimated from a general circulation model constrained by World
Ocean Circulation Experiment (WOCE) data. J. Geophys. Res., 108(C1): 3007, pp. 7-1-7-23. doi: 10.1029/2001JC001115.

STEWART RH. 2008. Introduction to Physical Oceanography. Texas, Texas A \& M University, 353 pp.

STOUFFER RJ, BROCCOLI AJ, DELWORTH TL, DIXON KW, GUDGEL R, HELD I, HEMLER R, KNUTSON T, LEE H-C, SCHWARZKOPF MD, SODEN B, SPELMAN MJ, WINTON M \& ZENG F. 2006. GFDL'S CM2 Global Coupled Climate Models. Part IV: Idealized Climate Response. Journal of Climate, American Meteorological Society, 19: 723-740.

STRAMMA L \& ENGLAND M. 1999. On the water masses and mean circulation of the South Atlantic Ocean. Journal of Geophysical Research, 104(C9): 20,863-20,883.

TALLEY LD, PICKARD GL, EMERY WJ \& SWIFT JH. 2011. Descriptive Physical Oceanography: An Introduction. $6^{\text {th }}$ ed. London, Elsevier, ISBN: 978-0-7506-4552-2. 555 pp.

TOMCZAK M \& GODFREY JS. 1994. Regional Oceanography: An Introduction. $1^{\text {st }}$ ed. Great Britain. ISBN 008041020. 391 pp.

WITTENBERG AT, ROSATI A, LAU N-C \& PLOSHAY JJ. 2006. GFDL'S CM2 Global Coupled Climate Models. Part III: Tropical Pacific Climate and ENSO. Journal of Climate, American Meteorological Society, 19: 698-722.

YAOHUA Z, ZEXUN W, YONGGANG W, YUPING G \& XINYI W. 2014. The annual mean sketches and climatological variability of the volume and heat transports through the inter-basin passages: A study based on 1400-year spin up of MOM4p1. Acta Oceanologica Sinica, 33(9): 12-24. doi: 10.1007/s13131-014-0513-7.

ZHENG Y \& GIESE BS. 2009. Ocean heat transport in Simple Ocean Data Assimilation: Structure and mechanisms. J. Geophys. Res., 114(C11009): 17 pp. doi: 10.1029/2008JC005190.

Recebido em 12 dezembro, 2013 / Aceito em 10 agosto, 2015

Received on December 12, 2013 / Accepted on August 10, 2015

\section{NOTES ABOUT THE AUTHORS}

Lívia Maria Barbosa Sancho. Majored in Oceanography by the Universidade do Estado do Rio de Janeiro and has a master degree in Civil Engineering with emphasis in the Oil and Gas field by the Alberto Luiz Coimbra Post-Graduation and Research in Engineering Institute. Currently, is a doctoral student degree at the Alberto Luiz Coimbra Post-Graduation and Research in Engineering Institute in the Program of Civil Engineering in Oil and Gas field. Main operating area is physical oceanography with emphasis on computational ocean modelling, mainly in the following fields: oceanic, atmospheric and sea ice climate variability and oceanographic data analysis.

Luiz Paulo de Freitas Assad. Graduated in Oceanography from the Universidade do Estado do Rio de Janeiro (1996). Master in Physical Oceanography from the Universidade de São Paulo (2000) and Ph.D. in Civil Engineering from the Alberto Luiz Coimbra Post-Graduation and Research in Engineering Institute (2006). Currently, is a Professor at the Meteorology Department of UFRJ in the area of interaction and modeling ocean-atmosphere. Has experience in Physical Oceanography, focusing on computational ocean modeling, acting on the following topics: global and regional ocean computational modeling, ocean-atmosphere interaction processes, computer modeling of pollutant dispersion and characterization and meteorological data analysis and oceanographic.

Luiz Landau. Majored in Civil Engineering by the Pontifícia Universidade Católica do Rio de Janeiro, master and doctoral degrees in Civil Engineering by the Universidade Federal do Rio de Janeiro. Currently, is a Professor at the Alberto Luiz Coimbra Post-Graduation and Research in Engineering Institute, Coordinator of LAMCE (Laboratório de Métodos Computacionais em Engenharia), Consultant of COPPETEC (Fundação Coordenação de Projetos, Pesquisas e Estudos Tecnológicos) and Coordinator of PRH-02 ANP/MCTI. 